\title{
Research Design for Testing Archaeological Site 41KA25 Karnes County FM 81: at Cibolo Creek
}

Joe T. Denton

Follow this and additional works at: https://scholarworks.sfasu.edu/ita

Part of the American Material Culture Commons, Archaeological Anthropology Commons, Environmental Studies Commons, Other American Studies Commons, Other Arts and Humanities Commons, Other History of Art, Architecture, and Archaeology Commons, and the United States History Commons

Tell us how this article helped you.

This Article is brought to you for free and open access by the Center for Regional Heritage Research at SFA ScholarWorks. It has been accepted for inclusion in Index of Texas Archaeology: Open Access Gray Literature from the Lone Star State by an authorized editor of SFA ScholarWorks. For more information, please contact cdsscholarworks@sfasu.edu. 


\section{Research Design for Testing Archaeological Site 41KA25 Karnes County FM 81: at Cibolo Creek}

\section{Licensing Statement}

This is a work produced for the Texas Department of Transportation (TxDOT) by the report producer. TXDOT and the report producer jointly own all rights, title, and interest in and to all intellectual property developed under TXDOT's contract with the report producer. The report may be cited and brief passages from this publication may be reproduced without permission provided that credit is given to both TXDOT and the report producer. Permission to reprint an entire chapter, section, figures or tables must be obtained in advance from either the Supervisor of the Archeological Studies Branch, Environmental Affairs Division, Texas Department of Transportation, 125 East 11th Street, Austin, Texas, 78701 or from the report producer. 


\title{
RESEARCH DESIGN FOR TESTING \\ ARCHAEOLOGICAL SITE 41KA25 \\ KARNES COUNTY \\ FM 81: AT CIBOLO CREEK
}

\author{
Joe T. Denton
}

Texas

State Department of Highways and Public Transportation Highway Design Division

May 1984 


\section{INTRODUCTION}

Archaeological Site 41KA25 is located on the east bank of Cibolo Creek on both sides of FM 81 in Karnes County. The site appears to be a multicomponent campsite which has been previously disrupted by highway construction and cultivation.

Testing of portions of the site within the proposed highway right-of-way is being initiated by the State Department of Highways and Public Transportation (SDHPT) in accordance with $\underline{\text { Procedures for the Protection of Historic and Cultural Properties }}$ (36 CR Part 800), procedures which are prescribed by law and endorsed by the Federal Highway Administration. Objectives of the test are to determine the nature of the site, its cultural affiliation and whether those portions included within the highway right-of-way meet the criteria for inclusion within the National Register of Historic Places.

Specifically, the testing will be to determine the depth of the deposits containing archaeological materials and to determine more precisely the limits of the site within the SDHPT right-ofway. Cultural context and stratification of materials present will also be of prime concern. In addition, cultural features, if encountered, will be pursued at least to the extent of determining the nature and possible affiliation and/or significance of those features. Where possible, artifacts and 
associated cultural debris will be recorded in situ.

Documentation will consist of field notes, level reports, drawings, and photographic record. 


\section{PROJECT DESCRIPTION}

The project consists of a federally funded on-system bridge replacement and approach roadway construction on FM 81 a t Cibolo Creek in Karnes County. The existing structure was built in 1951 and consists of a low-water bridge structure $100 \mathrm{ft}$. in length with a clear roadway of $20 \mathrm{ft}$. The replacement structure will be $300 \mathrm{ft}$. long with a clear roadway of $34 \mathrm{ft}$. The replacement structure will be constructed $35 \mathrm{ft}$. downstream of the existing structure. Detour during construction will utilize the existing structure. Some additional right-of-way will be required downstream to maintain a maximum right-of-way width of $80 \mathrm{ft}$. Total new right-of-way is one-half acre. 


\section{SITE DESCRIPTION}

Archaeological Site 41KA25 was initially recorded by Mr. Ken

Bishop in December 1971 and was resurveyed in 1984 by Daymond Crawford of the SDHPT cultural resources staff, in conjunction with the proposed SDHPT project. The initial survey reported the site to be located on either side of existing FM 81 on the east bank of Cibolo Creek. At that time, the site was reported to extend along the roadway approximately 75 yards beginning some 50 yards from the creek. In addition to disruptions caused by roadway construction, the site was noted to be under cultivation. A the time of resurvey, the portions of the site within the right-of-way were noted to be at least partially removed by routine right-of-way maintenance. Testing of the new right-ofway downstream of the existing facility was recommended. It will be this new location that will be emphasized during the current testing.

Cultural affiliations known to exist at the site consist of late Paleo-Indian and Archaic components. 


\section{TESTING PROCEDURES}

Archaeological testing will consist of hand-excavated units. Due to the limited size $(1 / 2$ acre $)$ of the new right-of-way, no fewer than 2 nor no more than 6 test units are anticipated to be necessary to determine the significance of the site within the proposed project. These units will be 1 X 2 meters and will be excavated in $10 \mathrm{~m}$ levels from ground surface to sterile deposits.

Horizontal control will be maintained by utilizing the SDHPT project centerline, a known line of exact legal declination. Vertical control will be maintained in relation to present ground surface of each test unit. Soil matrix excavated from the test units will be passed through $1 / 4$ in. hardware cloth, with all recovered artifacts and cultural debris being retained for analysis. Recovered materials will be bagged and labeled according to provenience and removed from the site to the SDHPT Archaeology Laboratory for temporary curation.

Horizontal placement of units will be based on surface observations. Some units will be placed along the perimeter of the site in order to determine exact site boundaries within the right-of-way.

Upon completion of the testing, a report detailing the results of 
the testing will be prepared with appropriate maps, profiles, and photographs. Additional recommendations will be made at that time, as well as determination of eligibility for inclusion within the National Register of Historic Places. 


\section{RESOURCE POTENTIAL}

At present and based on results of the 1971 survey and 1984 resurvey of Site $41 K A 25$, it is apparent that the site has potential to make a contribution to the ongoing expansion of the archaeological data base of Texas archaeology, particularly the region of central Coastal Texas. Survey indications are that the site has potential for the Paleo-Indian study unit $(12,000$ to 7000 B.P.) and the Archaic study unit (7000 B.P. to A.D. 500). A ny contribution to the Paleo-Indian study unit will be significant. The southeast and central Coastal Texas Archaic study unit is composed of two distinct regions. Site 41KA25 would be included in the central Coastal Archaic unit.

Contributions to the Archaic study unit would benefit the understanding of inland sites which perhaps are transitional from Coastal sites to Central Texas Archaic sites.

At present it is uncertain if Site $41 \mathrm{KA} 25$ would be beneficial to the Late Prehistoric or Historic study units. Potential will be substantially diminished should the site prove to be shallow and of mixed deposits. 